\title{
Corrigendum
}

\section{Living as a drug addict in Oslo, Norway - a study focusing on nutrition and health - Corrigendum}

M Sæland, M Haugen, F-L Eriksen, A Smehaugen, M Wandel, T Böhmer and A Oshaug

doi:10.1071/S1368980008002553, Published Online by Cambridge Unversity Press 13 June 2008

The first sentence of the Author contribution statement in the Acknowledgements should be replaced as follows:

Author contributions: M.S. is the head of the project and has carried out all parts of the research and is central in the writing of the paper.

\section{Reference}

Saeland M, Haugen M, Eriksen F-L, Smeghaugen A, Wandel M, Bohmer T \& Oshaug A. Living as a drug addict in Oslo, Norway - a study focusing on nutrition and health. Public Health Nutr 12(5), 630-636. 